some hoodoo-like rock formations, we were dazzled by a male Indigo Bunting, Lazuli Bunting, Field Sparrow, Lark Sparrow and Say's Phoebe - all demonstrating territorial behaviour. It was one of the most interesting lunches I have ever had.

These species may not be found on every trip, but most can be found with a bit of hiking and exploring along the valley. In addition to the bird life, this section of the valley has interesting geological formations and numerous wildflowers. A trip along this unique valley is always rewarding.

- John Pollock, Box 353, Whitewood, SK. SOG 5 CO

\section{NOTES FROM BIRCH HILLS}

I have three informational items.

First, I live on a quarter section of land where the farmyard is surrounded by trees. We don't have cats, consequently songbirds are not preyed upon by what has been called a privileged predator. One mid-morning during the first week of July I was drawn outside by the highly agitated voices of the three pairs of robins that nest here. When I got to where I could observe the cause of the noise, I was just in time to see the robins, soon joined by a pair of Eastern Kingbirds, mobbing a Big Brown Bat. The bat was making a valiant effort to evade the harassment, but the birds were extremely ferocious in their attacks and the bat was forced to fly into the adjacent aspens after which the birds returned to their respective territories.

I'd never seen such extreme behaviour from robins or kingbirds, not even when a Long-tailed Weasel skipped across the yard one week later. During the chase, the bat was making screeching sounds while the birds seemed to be cooperating in the attack. Two would fly alongside while a third one would fly close enough above the bat to peck at its head. Even though the wingspan of the bat appeared to be equal to the robins, there was no way he could avoid his tormentors.

The second item has to do with a different type of predation. Our farm water supply comes from a large dugout around which my wife and I have erected some bluebird/Tree Swallow nest boxes. One of these houses had seemed to be a death trap for the swallows and I was on the verge of destroying the box when, in late June, I happened to be going to the dugout to check on the shrubs we've planted there. I heard a commotion originating in the "killer" birdhouse and when I approached it, out flew a House Sparrow. When I opened the house, a Tree Swallow was in its death throes on the floor. The back of its head was bloody and its feathers in disarray.

Discussions with another birder suggested that House Sparrows have been suspected as killers in other areas of the province, particularly where nest box routes had been established. In addition, in all the instances of finding swallows dead in this particular house, there was no evidence of the bodies having been used as food. They seemed to have been killed simply because they were there. The solution to this problem became evident when I measured the entry hole and found it to be 1.5 inches. Subsequently, I cut out a piece of wood with a hole of 1.25 inches and nailed it over the "killer box" entry. Since then, though Tree Swallows have been observed going in and out of the box, no more dead swallows have been found.

Thirdly, on July 22, my wife and I were travelling from beach to beach 
on the west side of Waskesiu Lake, taking photographs and viewing the wildlife. At the very north end of Payton beach I happened to be scanning a group of 20 or so Ring-billed Gulls when I saw a couple of "gulls" that didn't seem quite right: their feet were red. Then, when I looked more carefully, I noticed that not only were there legs shorter, but that they looked more like terns, despite being the same size as gulls. A closer examination revealed a pair of Caspian Terns. We were able to take several photographs before the birds were spooked by the approach of several people. The terns flew north towards the Narrows.

- M. Maraschal, Box 301, Birch Hills, SK. SOJ OGO



